American Journal of Infectious Diseases 4 (2): 140-146, 2008

ISSN 1553-6203

(C) 2008 Science Publications

\title{
Retinoids and Opioids: Factors in the Development of HIV-Related Neurological Disease
}

\author{
${ }^{1,2}$ Walter Royal, III and ${ }^{3}$ Joseph L. Bryant \\ ${ }^{1}$ Department of Neurology, University of Maryland School of Medicine \\ ${ }^{2}$ Baltimore Veterans Administration Medical Center, Baltimore, MD, USA \\ ${ }^{3}$ Institute of Human Virology, University of Maryland, Baltimore, MD, USA
}

\begin{abstract}
Neurological disease occurs frequently in HIV-infected individuals and may occur at even higher rates among infected drug users. Among the potential mechanisms that promote such impairment, retinoid deficiency may have selective effects that could both lead to alterations in immune function and enhanced replication of HIV. Studies are currently underway to examine the possible selective effects of retinoid receptor activation and interactions with opioids on the pathogenesis of neurological disease in the transgenic rat model of HIV infection.
\end{abstract}

Key words: retinoids, opioids, retinoid receptors, HIV-1, neuro-AIDS; nervous system

\section{INTRODUCTION}

HIV-Related Neurological Disease and Drugs of Abuse: Neurological impairment due to HIV-1 (HIV) occurs commonly in infected individuals ${ }^{[1,2]}$. Evidence from a number of studies suggests that the frequency and severity of neurological disease that occur in the context of HIV infection can also be enhanced by illicit drug use. Recognized early days of the HIV epidemic as a risk factor for infection, the use of opioids (e.g., heroin), methamphetamine, and cocaine accounts for a disproportionately high percentage of AIDS cases overall. Despite this and the fact that neurological abnormalities can be commonly observed among illicit drug users ${ }^{[3]}$, there remain significant gaps in our understanding of the pathogenesis of neuro-AIDS in illicit drug users. In the case of opioids, studies suggest that these agents can modulate both immune function and infection efficiency through direct cellular effects. For example, morphine has been demonstrated to inhibit NF- $\mathrm{KB}$ binding in human monocytes and neutrophils activated with lipopolysacchride ${ }^{[4]}$ and to suppress proliferative responses to HIV antigens by lymphocytes while suppressing interferon responses and inducing apoptosis in these cells ${ }^{[5]}$. There are also a number of examples where morphine has been demonstrated to increase replication of HIV infection, including studies in which morphine enhanced production of virus by infected peripheral blood mononuclear cells following infection and in cocultures of HIV-infected promonocytic leukemia cells and human brain cells ${ }^{[6,7]}$.

In vivo, neuropathological studies have revealed evidence of HIV encephalitis more frequently in brains from HIV-infected opioid users as compared to infected gay males ${ }^{[8]}$, which also points to the modulatory effects of opioids on immune function and suggests that drug users may be at greater risk for developing HIV dementia. Clinically, HIV-infected individuals with a history of primarily opioid use may be demonstrated to have evidence of cognitive impairment more frequently than non-users ${ }^{[9]}$. Despite this difference, most studies have shown no increase in HIV disease progression among opioid users as compared to HIV-infected gay men ${ }^{[10,11,[3]}$. However, findings from a cohort of drug users in Edinburgh, Scotland demonstrate that the underlying factors that are associated with disease progression may differ for drug users and gay men, with drug users more often developing HIV encephalitis and central nervous system opportunistic processes occurring more frequently in gay men ${ }^{[8,12]}$. The specific mechanisms by which opioids change the natural history of CNS disease in infected individuals are not well understood and have been the focus of intense study.

Corresponding Author: Walter Royal, III, M.D., University of Maryland, School of Medicine, 655 West Baltimore Street Bressler Research Building, Room 12-031, Baltimore MD 21201 Tel: 410-706-4216, Fax: 410-706-0186 
Retinoids and Retinoid Receptors: The retinoids are a large family of biologically active agents that are chemically related to vitamin A and have a diverse range of effects on cell function. Retinol is the major form of vitamin A that is detectable in blood. Circulating retinol is largely derived from retinyl esters stored in hepatic stellate cells within cytoplasmic lipid droplets, which normally contain about $50-80 \%$ of total body vitamin $\mathrm{A}^{[13,14]}$. The retinyl esters are hydrolyzed and then secreted bound to retinol-binding protein (RBP) ${ }^{[15]}$, and the retinol-RBP complex then binds transthyretin (TTR) for transport to cells where it enters unmodified or after being first converted to all-trans retinoic acid ${ }^{[16,17]}$. The retinol that enters a cell is converted to retinal and then to all-trans retinoic acid (ATRA). ATRA, especially at higher concentrations, can then be converted into either 9-cis retinoic acid (9cis RA) or, to a lesser degree, 13-cis retinoic acid. ATRA and 9-cis RA, the major metabolically active products, are then bound by retinoid receptors, which, as a result of this interaction, become activated to bind specific elements in the promoter region of retinoidresponsive genes and/or members of the gene transcriptional complex to modulate gene expression ${ }^{[18]}$. These retinoid receptors, identified as retinoic acid receptor (RAR) and retinoic $\mathrm{X}$ receptor (RXR) $[19,20,21,22]$, can exist as RAR-RXR heterodimers or RXR-RXR homodimers. The retinoid receptors are synthesized as $\alpha, \beta$, and $\gamma$ subtypes and exist in cells in heterodimer combinations that are cell type specific ${ }^{[23]}$. The primary ligand for RAR is ATRA whereas 9-cis RA can bind either RAR or RXR; 13-cis retinoic acid has been reported to also bind either RAR or RXR.

Immunological Effects of Retinoids: Retinoid have been demonstrated to have significant effects on immune function. In animals, retinoids have been generally shown to suppress proinflammatory responses in activated immune cells ${ }^{[24,25,26,27,28,29,30]}$. In contrast, vitamin A deficiency in experimental animals is characteristically associated with enhanced proinflammatory immune responses, effects that can be reversed by vitamin A supplementation ${ }^{[31,32,33,29,34]}$. In contrast, studies of vitamin A deficiency in humans can show a mixed picture, with findings that can be seen as due to enhanced or suppressed immune response. This may be due to the fact that, in contrast to what is observed in animals with experimental deficiency, chronic depletion of vitamin $\mathrm{A}$ in humans may be associated with a chronic illness, such as HIV infection or liver or renal disease, and with deficiency of other nutrients that are important for the maintenance of a normal immune function, such as zinc and selenium. For example, vitamin A deficient children were found to have lower naive and higher memory $\mathrm{T}$ cell percentages in blood, and these numbers were reversed by treatment with vitamin $\mathrm{A}^{[35]}$. In other human studies, vitamin A deficiency resulted in decreased cellmediated immune function ${ }^{[36,37]}$ and antibody responses [36] and in lower numbers of CD4+ lymphocytes, all which also normalized following vitamin A administration ${ }^{[30,35,38] \text {. }}$

\section{RESULTS}

Retinoids and HIV Infection: In vitro studies have demonstrated that retinoids can either enhance or suppress replication of HIV in infected cultures. Factors that appear to influence which effect is observed include the specific retinoid utilized, when infection is initiated relative to exposure to the retinoid, and whether the cells have been exposed to another activating stimulus ${ }^{[39,40,41,42,43]}[42,44,45,46][39,45,44,47]$. In clinical studies involving patients with HIV infection, 13-cis retinoic acid induced regression of oral leukoplakia [48], and AIDS-related Kaposi's sarcoma lesions have been shown resolve with treatment with topical preparations of either 9-cis RA or the synthetic RXR-specific retinoid agonist bexarotene ${ }^{[49,50]}$ A candidate target for these effects is the viral LTR, which contains the promoter elements that are required for expression of the HIV genome ${ }^{[39,51]}$. Notably, a retinoic acid response element has been demonstrated in the HIV long terminal repeat (LTR) which can be inhibited by ATRA and 9-cis RA acid through activation of RAR- $\alpha$ and RXR- $\alpha^{[39] \text {. }}$

In the setting of HIV infection, vitamin A deficiency has been associated with more frequent mother to child transmission of HIV by pregnant women, both in Malawi and in the United States ${ }^{[52,53]}$. Independent of the HIV status of the mother, deficiency is also associated with retardation of growth and development of the child following birth ${ }^{[54]}$. In recent studies it was shown that both periodic supplementation and a single high dose of vitamin A given during the post-partum period can improve survival among HIV 
infected children who are supplemented at, respectively, 6 months and 6 weeks of age ${ }^{[55,56]}$. For children supplemented at age 6 weeks, however, benefit was seen only for those who were negative for HIV infection at baseline but were positive at 6 weeks of age [56]. These findings not only demonstrate the potential beneficial effects of retinoid repletion in this setting, but also the selective nature of these effects. In studies of injection drug users, vitamin A deficiency was associated with low CD4+ $\mathrm{T}$ cell counts, more rapid progression to AIDS, and an increased mortality ${ }^{[57,58]}$. Low serum retinol levels did not correlate with plasma

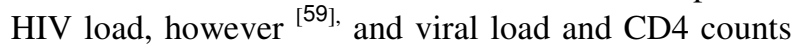
were not affected by vitamin A supplementation $(60 \mathrm{mg}$ of oral retinol equivalent) ${ }^{[59]}$. This may reflect the fact that these individuals were likely to be also deficient in other micronutrients. However, these findings, again, reflect the complex mechanisms that underlie these effects.

Immunomodulatory Effects of Retinoids and Opioids on Activated Immune Cells: In studies that showed increased HIV progression in vitamin Adeficient drug users, it was also possible that the observed clinical outcomes might have resulted from impaired interactions between the opioid and retinoid systems in cells, resulting in deleterious effects on the immune status of these individuals. Therefore, such potential interactions in vitro using U937 cells, a human mononuclear cell (myelomonocytic) cell line were studied ${ }^{[60]}$. The cells were incubated with retinoid agonist and/or antagonist then activated with PHA alone or in the presence of morphine. The effects of these treatments on proinflammatory cytokine responses in these cells was examined by measuring TNF- $\alpha$ gene expression by PCR, the percentage of cells that were positive for this cytokine using flow cytometry, and protein secretion by ELISA. These studies revealed that, in the absence of morphine, TNF$\alpha$ production was increased by PHA activation and this effect was suppressed by the retinoid agonists but not by the antagonists and suppressed following incubation with both retinoid agonist and antagonists. Interestingly, in the context of activating RXR or inhibiting RAR with, respectively, a selective agonist or antagonist, the suppressive retinoid effect was inhibited by morphine through morphine binding to $\mathrm{mu}$ opioid receptor (MOR). Furthermore, RXR agonists and RAR antagonists increased activation of the MOR gene promoter and intracytoplasmic and surface protein expression. Therefore, these studies demonstrate a specific modulatory effects of morphine on retinoidinduced suppression of TNF- $\alpha$ production activated U937 cells.

The Transgenic Rat Model of HIV Infection: The HIV-1 transgenic rat was produced using fertilized eggs that were microinjected with pNL4-3 proviral DNA rendered non-infectious by the removal of a fragment that encompasses the 3' region of gag and the 5' region of pol ${ }^{[61]}$. The transgene, however, remains under control of the HIV-1 LTR and, therefore, can encode mRNA for env, vif, tat, and nef ${ }^{[62]}$. Replication of the incorporated viral genes occurs in circulating immune cells, spleen, lymph nodes, skin, and in the nervous system of the transgenic rat, and the animals develop abnormalities in all of the systems that express virus, including pathological features of HIV encephalitis ${ }^{[61]}$. The rats also develop clinical immunodeficiency with impaired delayed-type hypersensitivity and antigenspecific antibody responses [61]. The transgenic rats also over time develop $\mathrm{T}$ cell abnormalities with increased percentages of naïve CD4+ and CD8+ T cell subsets and decreased percentages of effector/memory subsets, impaired generation of Th1 (pro-inflammatory) cytokine responses with a reduction in $\mathrm{T}$ cells expressing IFN- $\gamma$ and decreased IFN- $\gamma$ secretion, increased activation-induced apoptosis of $\mathrm{T}$ lymphocytes, and increased splenic $\mathrm{T}$ cell proliferative responses to mitogen stimulation ${ }^{[63,61]}$. In studies of vitamin A deficiency using the transgenic rat, $\mathrm{T}$ cells from deficient animals produced higher levels of IFN- $\gamma$ and secreted increased amounts of TNF- $\alpha$ than what was observed for non-deficient rats [64]. In addition, transgenic rats with vitamin A deficiency produced higher levels of MOR mRNA than non-deficient rats and wild type rats on either diet. Finally, expression of levels of HIV env and nef mRNA was higher for the transgenic rats with vitamin A deficiency than for rats in the other groups. These data demonstrate that both immune and viral effects can be observed in an in vivo model of HIV infection and vitamin A deficiency. Studies in this model could greatly contribute to our understanding of the mechanisms that underlie the development of neurological impairment in humans with a history of HIV infection and drug use. 


\section{DISCUSSION}

Retinoids induce immunomodulatory and virologic effects that appear to be clinically beneficial to patients with HIV infection. The mechanisms that underlie these effects remain to be fully defined, but likely include effects from activation of specific retinoid receptor subtypes in immune cells as well as other cells that may be infected by the virus. The HIV-1 transgenic rat provides an ideal model for studies of factors that might modulate the pathogenic mechanisms that underlie the development of HIV-1 related abnormalities in these animals and, by extrapolation, in humans. Studies utilizing this model will likely shed light on approaches for developing therapeutic strategies for treating patients with HIV-related neurological disease.

\section{REFERENCES}

1. Britton, C. B. and Miller, J. R., 1984. Neurologic complications in acquired immunodeficiency syndrome (AIDS). Neurol.Clin., 2 (2): 315-339.

2. Levy, R. M., Bredesen, D. E., and Rosenblum, M. L., 1985. Neurological manifestations of the acquired immunodeficiency syndrome (AIDS): experience at UCSF and review of the literature. Journal of Neurosurgery, 62 (475-95.

3. Royal, W. 3d, Updike, M., Selnes, O. A., Proctor, T. V., Nance-Sproson, L., Solomon, L., Vlahov, D., Cornblath, D. R., and McArthur, J. C., 1991. HIV-1 infection and nervous system abnormalities among a cohort of intravenous drug users. Neurology, 41 (12): 1905-1910.

4. Welters, I. D., Menzebach, A., Goumon, Y., Cadet, P., Menges, T., Hughes, T. K., Hempelmann, G., and Stefano, G. B., 2000. Morphine inhibits NFkappaB nuclear binding in human neutrophils and monocytes by a nitric oxide-dependent mechanism. Anesthesiology, 92 (6): 1677-1684.

5. Nair, M. P. N., Schwartz, S. A., Polasani, R., Hou, J., Sweet, A., and Chadha, K. C., 1997. Immunoregulatory effects of morphine on human lymphocytes. Clin Diag Immunol, 4 (2): 127-132.

6. Peterson, P. K., Gekker, G., Hu, S., Anderson, W. R., Kravitz, F., Portoghese, P. S., Balfour, H. H., Jr., and Chao, C. C., 1994. Morphine amplifies HIV-1 expression in chronically infected promonocytes cocultured with human brain cells. J Neuroimmunol., 50 (2): 167-175.
7. Peterson, P. K., Sharp, B. M., Gekker, G., Portoghese, P. S., Sannerud, K., and Balfour, H. H., Jr., 1990. Morphine promotes the growth of HIV-1 in human peripheral blood mononuclear cell cocultures. AIDS, 4 (9): 869-873.

8. Bell, J. E., Brettle, R. P., Chiswick, A., and Simmonds, P., 1998. HIV encephalitis, proviral load and dementia in drug users and homosexuals with AIDS. Effect of neocortical involvement. Brain, 121 (2043-2052.

9. Bouwman, F. H., Skolasky, R. L., Hes, D., Selnes, O. A., Glass, J. D., Nance-Sproson, T. E., Royal, W., Dal Pan, G. J., and McArthur, J. C., 1998. Variable progression of HIV-associated dementia. Neurology, 50 (6): 1814-1820.

10. Selnes, O. A., Galai, N., McArthur, J. C., Cohn, S., Royal, W. 3rd, Esposito, D., and Vlahov, D., 1997. HIV infection and cognition in intravenous drug users: long-term follow-up. Neurology, 48 (1): 223-230.

11. Selnes, O. A., McArthur, J. C., Royal, W. 3d, Updike, M. L., Nance-Sproson, T., Concha, M., Gordon, B., Solomon, L., and Vlahov, D., 1992. HIV-1 infection and intravenous drug use: longitudinal neuropsychological evaluation of asymptomatic subjects. Neurology, 42 (10): 19241930.

12. Tomlinson, G. S., Simmonds, P., Busuttil, A., Chiswick, A., and Bell, J. E., 1999. Upregulation of microglia in drug users with and without presymptomatic HIV infection. Neuropathol.Appl.Neurobiol., 25 (5): 369-379.

13. Blumhoff, R., Berg, T., and Norum, K. R., 1988. Transfer of retinol from parenchymal to stellate cells in liver is mediated by retinol-binding protein. Proceedings of the National Adacemy of Sciences,USA, 85 (3455-3458.

14. Blomhoff, R., Helgerud, P., Rasmussen, M., Berg, T., and Norum, K. R., 1982. In vivo uptake of chylomicrom [3H]retinyl ester by rat lever: evidence for retinol transfer from parenchymal to nonparenchymal cells. Proceedings of the National Adacemy of Sciences,USA, 79 (7326-7330.

15. Kanai, M., Raz, A., and Goodman, D. S., 1968. Retinol-binding protein: the transport protein for vitamin A in human plasma. Journal of Clinical Investigation, 47 (2025-2044. 
16. van Jaarsveld, P. P., Edelhoch, H., DeWitt, S. G., and Robbins, J., 1973. Ther interaction of human plasma retinol-binding protein with prealbumin. Journal of Biological Chemistry, 248 (4698-4705.

17. Monaco, H. L., Rizzi, M., and Coda, A., 1995. Structure of a complex of two plasma proteins: transthyretin and retinol-binding protein. Science, 268 (1030-1041.

18. Mangelsdorf, D. J., Umesono, K., and Evans, R. M., 1994. The retinoid receptors (Sporn, M. B., Roberts, A. B., and Goodman, D. S.) pp. 319-350. Raven Press, New York.

19. Burri, B. J. and Kutnick, M. A., 1987. High performance liquid chromatographic test for retinol binding protein. Clinical Chemistry, 33 (935-935.

20. Mangelsdorf, D. J., Ong, E. S., Dyck, J. A., and Evans, R. M., 1990. Nuclear receptor that identifies a novel retinoic acid-response pathway. Nature, 345 (224-229.

21. Heyman, R. A., Mangelsdorf, D. J., Dyck, J. A., Stein, R. B., Eichele, G., Evans, R. M., and Thaller, C., 1992. 9-cis-retinoic acid is a high affinity ligand for the retinoid X receptor. Cell, 68 (397406.

22. Levin, A. A., Sturzenbecker, L. J., Kazmer, S., Bosakowski, T., Huselton, C., Allenby, G., Speck, J., Kratzeisen, C., Rosenberger, M., Lovey, A., and Grippo, J. F., 1992. 9-cis-Retinoic acid stereoisomer binds and activates the nuclear receptro RXR alpha. Nature, 355 (359-361.

23. Sappey, C., Leclercq, P., Coudray, C., Faure, P., Micoud, M., and Favier, P., 1994. Vitamin, trace element and peroxide status in HIV seropositive patients: asymptomatic patients present a severe $\beta$ carotene deficiency. Clin Chim Acta, 230 (35-42.

24. Na, S. Y., Kang, B. Y., Chung, S. W., Han, S. J., Ma, X., Trinchieri, G., Im, S. Y., Lee, J. W., and Kim, T. S., 3-19-1999. Retinoids inhibit interleukin-12 production in macrophages through physical associations of retinoid $\mathrm{X}$ receptor and NFkappaB. J Biol.Chem., 274 (12): 7674-7680.

25. Massacesi, L., Castigli, E., Vergeli, M., Olivotto, J., Abbamondi, A. L., Sarlo, F., and Amaducci, L., 1991. Immunosuppressive activity of 13-cisretinoic acid and prevention of experimental autoimmune encephalomyelitis in rats. $\mathrm{J}$ Clin Invest, 88 (1331-1337.

26. Sidell, N. and Ramsdell, F., 1988. Retinoic acid upregualtes interleukin-2 receptors an activated human thymocytes. Cell, 115 (299-309.
27. Chen, W. and Wahl, S. M., 1999. Manipulation of TGF-beta to control autoimmune and chronic inflammatory diseases. Microbes.Infect., 1 (15): 1367-1380.

28. Qu, Z. X., Dayal, A., Jensen, M. A., and Arnason, B. G., 1998. All-trans retinoic acid potentiates the ability of interferon beta-1b to augment suppressor cell function in multiple sclerosis. Arch Neurol, 55 (315-321.

29. Carman, J. A. and Hayes, C. E., 1991. Abnormal regulation of IFN-gamma secretion in vitamin A deficiency. J Immunol, 147 (1247-1252.

30. Ballow, M., Xiang, S., Wang, W., and Brodsky, L., 1996. The effects of retinoic acid on immunoglobulin synthesis: a role of interleukin 6 . Journal of Clinical Immunology, 16 (171-179.

31. Cantora, M. T., Nashold, F. E., Chun, T. Y., and Hayes, C. E., 1996. Vitamin A down-regulation of IFN-gamma synthesis in cloned mouse Th1 lymphocytes depends on the CD28 costimulatory pathway. Journal of Immunology, 156 (2674-2679.

32. Cantorna, M. T., Nashold, F. E., and Hayes, C. E., 1995. Vitamin A deficiency results in a priming environment conducive for Th1 cell development. Eu J Immunol, 25 (1673-1679.

33. Cantorna, M. T., Nashold, F. E., and Hayes, C. E., 1994. In vitamin A deficiency multiple mechanisms establish a regulatory $\mathrm{T}$ helper cell imbalance with excess Th1 and insufficient Th2 function. J Immunol, 152 (1515-1522.

34. Chun, T. Y., Carman, J. A., and Hayes, C. E., 1992. Retinoid repletion of vitamin A-deficient mice restores IgG responses. J Nutr, 122 (10621069.

35. Semba, R. D., Muhilal, Ward, B. J., Griffin, D. E., Scott, A. L., Natadisastra, G., West, J. K. P., and Sommer, A., 1993. Abnormal T-cell subset proportions in vitamin-A-deficient children. Lancet, 341 (5-8.

36. Semba, R. D., Muhalil, Scott, A. L., Natadisastra, G., Wirasasmita, S., Mele, L., Ridwan, E., West, K. P., and Sommer, A., 1991. Depressed immune response to tetanus in children with vitamin $\mathrm{A}$ deficiency. Journal of Nutrition, 122 (101-107.

37. Ward, B. J., Humphrey, J. H., Clement, L., and Chaisson, R. E., 1993. Vitamin A status in HIV infection. Nutrition Research, 13 (157-166. 
38. MacDonald, P. N., Bok, D., and Ong, D. E., 1990. Localization of cellular retinol-binding protein and retinol-binding protein in cells comprising the blood-brain barrier of rat and human. Proc Natl Acad Sci USA, 87 (4265-4269.

39. Yamaguchi, K., Groopman, J. E., and Byrn, R. A., 1994. The regulation of HIV by retinoic acid correlates with cellular expression of the retinoic acid receptors. AIDS, 8 (12): 1675-1682.

40. Kitano, K., Baldwin, G. C., Raines, M. A., and Golde, D. W., 11-15-1990. Differentiating agents facilitate infection of myeloid leukemia cell lines by monocytotropic HIV-1 strains. Blood, 76 (10): 1980-1988.

41. Cannon, P. M., Ellis, I. O., Blamey, R. W., Bell, J., Elston, C. W., and Robertson, J. F., 1993. Expression of tumour-associated antigens in breast cancer primary tissue compared with serum levels. Eur.J Surg.Oncol., 19 (6): 523-527.

42. Semmel, M., Macho, A., Coulaud, D., Alileche, A., Plaisance, S., Aguilar, J., and Jasmin, C., 10-151994. Effect of retinoic acid on HL-60 cells infected with human immunodeficiency virus type 1. Blood, 84 (8): 2480-2488.

43. Pautrat, G., Suzan, M., Salaun, D., Corbeau, P., Allasia, C., Morel, G., and Filippi, P., 1990. Human immunodeficiency virus type 1 infection of U937 cells promotes cell differentiation and a new pathway of viral assembly. Virology, 179 (2): 749758.

44. Poli, G., Kinter, A. L., Justement, J. S., Bressler, P., Kehrl, J. H., and Fauci, A. S., 4-1-1992. Retinoic acid mimics transforming growth factor beta in the regulation of human immunodeficiency virus expression in monocytic cells. Proc Natl Acad Sci U S A, 89 (7): 2689-2693.

45. Towers, G., Harris, J., Lang, G., Collins, M. K., and Latchman, D. S., 1995. Retinoic acid inhibits both the basal activity and phorbol ester- mediated activation of the HIV long terminal repeat promoter. AIDS, 9 (2): 129-136.

46. Goldman, R., 1984. Effect of retinoic acid on the proliferation and phagocytic capability of murine macrophage-like cell lines. J Cell Physiol, 120 (1): 91-102.

47. Maciaszek, J. W., Coniglio, S. J., Talmage, D. A., and Viglianti, G. A., 1998. Retinoid-induced repression of human immunodeficiency virus type 1 core promoter activity inhibits virus replication. $\mathbf{J}$ Virol., 72 (7): 5862-5869.
48. Beenken, S. W., Huang, P., Sellers, M., Peters, G., Listinsky, C., Stockard, C., Hubbard, W., Wheeler, R., and Grizzle, W., 1994. Retinoid modulation of biomarkers in oral leukoplakia/dysplasia. J Cell Biochem.Suppl, 19 (270-277.

49. Walmsley, S., Northfelt, D. W., Melosky, B., Conant, M., Friedman-Kien, A. E., and Wagner, B., 11-1-1999. Treatment of AIDS-related cutaneous Kaposi's sarcoma with topical alitretinoin (9-cis-retinoic acid) gel. Panretin Gel North American Study Group. J Acquir.Immune.Defic.Syndr., 22 (3): 235-246.

50. Duvic, M., Friedman-Kien, A. E., Looney, D. J., Miles, S. A., Myskowski, P. L., Scadden, D. T., Von Roenn, J., Galpin, J. E., Groopman, J., Loewen, G., Stevens, V., Truglia, J. A., and Yocum, R. C., 2000. Topical treatment of cutaneous lesions of acquired immunodeficiency syndrome-related Kaposi sarcoma using alitretinoin gel: results of phase 1 and 2 trials. Arch Dermatol, 136 (12): 1461-1469.

51. Lee, M. O., Hobbs, P. D., Zhang, X. K., Dawson, M. I., and Pfahl, M., 6-7-1994. A synthetic retinoid antagonist inhibits the human immunodeficiency virus type 1 promoter. Proc Natl Acad Sci U S A, 91 (12): 5632-5636.

52. Greenberg, B. L., Semba, R. D., Vink, P. E., Farley, J. J., Sivapalasingam, M., Steketee, R. W., Thea, D. M., and Schoenbaum, E. E., 1997. Vitamin A deficiency and maternal-infant transmissions of HIV in two metropolitan areas in the United States. AIDS, 11 (3): 325-32.

53. Semba, R. D., Miotti, P. G., Chiphangui, J. D., Saah, A. J., Conner, J. K., Dallabetta, G. A., and Hoover, D. R., 1994. Maternal vitamin A deficiency and mother-to-child transmission of HIV-1. Lancet, 343 (1593-1697.

54. Kennedy, C. M., Kuhn, L., and Stein, Z., 2000. Vitamin A and HIV infection: disease progression, mortality, and transmission. Nutr.Rev., 58 (10): 291-303.

55. Semba, R. D., Ndugwa, C., Perry, R. T., Clark, T. D., Jackson, J. B., Melikian, G., Tielsch, J., and Mmiro, F., 2005. Effect of periodic vitamin A supplementation on mortality and morbidity of human immunodeficiency virus-infected children in Uganda: A controlled clinical trial. Nutrition, 21 (1): 25-31. 
56. Humphrey, J. H., Iliff, P. J., Marinda, E. T., Mutasa, K., Moulton, L. H., Chidawanyika, H., Ward, B. J., Nathoo, K. J., Malaba, L. C., Zijenah, L. S., Zvandasara, P., Ntozini, R., Mzengeza, F., Mahomva, A. I., Ruff, A. J., Mbizvo, M. T., and Zunguza, C. D., 3-15-2006. Effects of a single large dose of vitamin $\mathrm{A}$, given during the postpartum period to HIV-positive women and their infants, on child HIV infection, HIV-free survival, and mortality. Journal of Infectious Diseases, 193 (6): 860-871.

57. Semba, R. D., Caiaffa, W. T., Graham, N. M., Cohn, S., and Vlahov, D., 1995. Vitamin A deficiency and wasting as predictors of mortality in human immunodeficiency virus-infected injection drug users. Journal of Infectious Diseases, 171 (1196-1202.

58. Weber, T., B:uttner, W., and Felgenhauer, K., 1987. Evidence for different immune responses to HIV in CSF and serum? Klin.Wochenschr., 65 (259-63.

59. Semba, R. D., Lyles, C. M., Margolick, J. B., Caiaffa, W. T., Farzadegan, H., Cohn, S., and Vlahov, D., 1998. Vitamin A supplementation and human immunodeficiency virus load in injection drug users. J Infect.Dis., 177 (3): 611-616.

60. Mou, L., Lankford-Turner, P., Leander, M. V., Bissonnette, R. P., Donahoe, R. M., and Royal, W., 2004. RXR-induced TNF-alpha suppression is reversed by morphine in activated U937 cells. Journal of Neuroimmunology, 147 (1-2): 99-105.
61. Reid, W., Sadowska, M., Denaro, F., Rao, S., Foulke, J., Jr., Hayes, N., Jones, O., Doodnauth, D., Davis, H., Sill, A., O'Driscoll, P., Huso, D., Fouts, T., Lewis, G., Hill, M., Kamin-Lewis, R., Wei, C., Ray, P., Gallo, R. C., Reitz, M., and Bryant, J., 7-31-2001. An HIV-1 transgenic rat that develops HIV-related pathology and immunologic dysfunction. Proc.Natl.Acad.Sci.U.S.A, 98 (16): 9271-9276.

62. Mazzucchelli, R., Amadio, M., Curreli, S., Denaro, F., Bemis, K., Reid, W., Bryant, J., Riva, A., Galli, M., and Zella, D., 2004. Establishment of an ex vivo model of monocytes-derived macrophages differentiated from peripheral blood mononuclear cells (PBMCs) from HIV-1 transgenic rats. Mol.Immunol., 41 (10): 979-984.

63. Reid, W., Abdelwahab, S., Sadowska, M., Huso, D., Neal, A., Ahearn, A., Bryant, J., Gallo, R. C., Lewis, G. K., and Reitz, M., 3-30-2004. HIV-1 transgenic rats develop $\mathrm{T}$ cell abnormalities. Virology, 321 (1): 111-119.

64. Royal, W., III, Wang, H., Jones, O., Tran, H., and Bryant, J. L., 2007. A vitamin A deficient diet enhances proinflammatory cytokine, $\mathrm{Mu}$ opioid receptor, and HIV-1 expression in the HIV-1 transgenic rat. Journal of Neuroimmunology, 185 (1-2): 29-36. 